\title{
AN ANALYTICAL OVERVIEW OF DOCTRINE OF FINALITY AND JUDICIAL RESPONSE IN INDIA
}

\author{
Dr Vikrant Sopan Yadav \\ Associate Professor (Law), \\ National Institute of Construction Management and Research, \\ Hyderabad
}

Article DOI: https://doi.org/10.36713/epra6078

\begin{abstract}
Supreme Court of India, being the highest court of the country, has always had the air of finality to its pronouncements. The doctrine of finality has played a great role in giving judiciary the upper hand and finality to its judgements. It has helped the judiciary in keeping other pillars of democracy i.e. executive and legislature form transgressing their powers laid in the constitution.

This research paper contains an analysis of concept of finality/res judicata and judicial response to the doctrine of finality in India.
\end{abstract}

KEY WORDS: Finality, res judicata, judgement, litigation

\section{INTRODUCTION}

Finality of judgments puts an end to the judicial process, prohibiting subsequent appeals, new proceedings and disputing clearly established facts. Finality to judicial decision, popularly known as doctrine of res judicata in Indian parlance, has been recognised by $\mathrm{u} / \mathrm{s} 11$ of the Code of Civil Procedure. Section 11 of the code states that no court shall attempt any suit or issue in which the matter directly or substantially in issue is the same in the previous or former suit between the same parties or between under whom they or any of them claim litigation under the same title of the former suit already decided before any competent court to attempt such subsequent suit.

The issues which are litigated or maybe litigated in an action can be finally adjudicated only by final judgment on the merits. Discontinuance or abatement of the action before final judgment leaves the issues open to contest in other litigation, even though they had been decided provisionally by order entered upon a motion made in the action or by interlocutory judgment. "The test then is not the form of the decision but the nature of the proceedings in which the adjudication is made. ${ }^{1}$

\section{HISTORY OF DOCTRINE OF FINALITY}

Roots of the doctrine of Res Judicata can be found in the various ancient legal systems. Starting from the issue preclusion in the Germanic estoppel to the latter on the Roman res judicata which was instigating the truth by looking into the judgmental effect. ${ }^{2}$ The doctrine of Res Judicata is based on three Roman Maxims ${ }^{3}$ :

\begin{abstract}
Nemo debet lis vaxari pro eaderm causa (no man should be vexed twice for the same cause);
\end{abstract}

Interest republicae ut sit finis litium (it is in the interest of the state that there should be an end to a litigation); ${ }^{4}$ and

Re judicata pro veritate occipitur (a judicial decision must be accepted as correct).

\footnotetext{
${ }^{2}$ Clermont K.M., Res Judicata as Requisite for Justice, 68 Rutgers University Law Review (2016) https://scholarship.law.cornell.edu/cgi/viewcontent.c gi article $=2599 \&$ context $=$ facpub

${ }^{3}$ Takwani C.K., Civil Procedure with Limitation Act, 1963, EBC Explorer, pg. 70-71, 8th ed. 2017.

4 Chanchal Kumar Chatterjee v. State of West Bengal, 12 W. P. 4398 (W) of 2018
} 
The logical reasoning behind principle of res judicata is that, "where a fair opportunity has been afforded to the parties to litigate a claim be-fore a court which has jurisdiction over the parties and the cause of action, and the court has finally decided the controversy, the interests of the state and of the parties require that the validity of the claim and any issue actually litigated in the action, shall not be again litigated by them.' 5

\section{CONCEPT OF RES JUDICATA/FINALITY OF JUDGEMENT}

Res judicata may comprise a degree of either claim preclusion or issue preclusion. Claim preclusion subdivides into three subparts:

(1) If the judgment in the initial action was in the defendant's favor, the plaintiff's claim is said to be barred by the judgment. Bar says that the plaintiff generally cannot bring a second action on the claim in the hope of winning this time.

(2) If the judgment in the initial action was in the plaintiffs favor, the plaintiffs claim is said to merge in the judgment. Merger says that the plaintiff generally cannot bring a second action on the claim in the hope of winning a more favorable judgment.

(3) However, the plaintiff can seek to enforce the favorable judgment, and the defendant cannot then raise defenses that were or could have been interposed in that initial action. ${ }^{6}$

Issue preclusion is the part of res judicata that says, outside the context of the initial action, regardless of who won the judgment, a party generally may not relitigate any issue of fact or law if its determination was essential to a valid and final judgment, subject to exceptions. $^{7}$

\section{DOCTRINE OF FINALITY AND JUDICIAL RESPONSE}

Justice Dalveer Bhandari and Justice H.L. Dattu of the Supreme Court of India have examined the concept of finality of judgment in Indian Council for Enviro-Legal Action v. Union of India \& Ors. ${ }^{8}$ In the instant case, even after final judgment of this court, the review petition was also dismissed. Thereafter, even the curative petition has also been dismissed in this case. Court held that,

'The controversy between the parties must come to an end at some stage and the judgment of this court must be permitted to acquire finality. It would hardly

\footnotetext{
${ }^{5}$ Restatement, Judgments (Tent. Draft No. 1,1941) $\S 301$.

${ }^{6}$ Supra note, 2 pg. 1070

${ }^{7}$ See Restatement (Second) of Judgments $§ 27-28$

(AM. LAW INST. 1982).

${ }^{8} 1996$ AIR 1446, 1996 SCC (3) 212
}

be proper to permit the parties to file application after application endlessly. 'In a country governed by the rule of law, finality of the judgment is absolutely imperative and great sanctity is attached to the finality of the judgment. Permitting the parties to reopen the concluded judgments of this court by filing repeated interlocutory applications is clearly an abuse of the process of law and would have far reaching adverse impact on the administration of justice.'

Court also held that,

The maxim 'interest Republicae ut sit finis litium' says that it is for the public good that there be an end of litigation after a long hierarchy of appeals. At some stage, it is necessary to put a quietus. It is rare that in an adversarial system, despite the judges of the highest court doing their best, one or more parties may remain unsatisfied with the most correct decision. Opening door for a further appeal could be opening a flood gate which will cause more wrongs in the society at large at the cost of rights.

Sanjib Banerjee, J. had examined the issue with regard to the Doctrine of Finality and pronounced the principles thereto in Indu Bhusan Jana v. Union of India and Ors. ${ }^{9}$ The Principles of Doctrine of Finality have been succinctly captured in the paragraphs delineated below:

"11. Upon an order attaining finality, it matters little as to whether it was erroneous. A party aggrieved by an order has to work out his remedies within the legal framework. If an issue or the entire lis is concluded upon a finding being rendered and such finding remains unchallenged, it is no longer open to the party to undo the effect thereof at any subsequent stage or collaterally unless it is demonstrated that the finding was obtained by fraud or the Court lacked jurisdiction to pass the order. The hierarchy in the judiciary exists to afford litigants to climb up the ladder in pursuit of justice and to right a wrong committed at a lower level. But if a litigant accepts an order, he does it to his prejudice and binds himself thereby.

Court further observed that,

12. The principle of finality or res judicata is a matter of public policy and is one of the pillars on which a judicial system is founded. Once a judgement becomes conclusive, the matters in issue covered thereby cannot be reopened unless fraud or mistake or lack of jurisdiction is cited to challenge it directly at a later stage. The

\footnotetext{
${ }^{9}$ AIR 2009 Cal 24; (2009) 1 CHN 27
} 
principle is rooted to the rationale that the issues decided may not be reopened, and has little to do with the merit of the decision. If it were to be otherwise, no dispute can be resolved or concluded. The principles of res judicata and constructive res judicata apply equally to proceedings under Article 226 of the Constitution.

Similarly, in M. Nagabhushana v. State of Karnataka $^{10}$ this Court held that the doctrine of res judicata is not a technical doctrine but a fundamental principle which sustains the rule of law in ensuring finality in litigation. The main object of the doctrine is to promote a fair administration of justice and to prevent abuse of process of the court on the issues which have become final between the parties.

In the case of Satyadhyan Ghosal v. Deorjin Debi, ${ }^{11}$ Das Gupta, J explained the doctrine in following words;

"The principle of res judicata is based on the need of giving finality to judicial decisions. What it says is that once a res is judicata, it shall not be adjudged again. Primarily, it applies as between past litigation and future litigation. When a matter whether on a question of fact or a question of a decision is final, either because no appeal was taken on higher court or because the appeal was dismissed, or no appeals lies, neither party will lie, neither part will be allowed in future suit bar proceeding between the same parties to canvass the matter again"12

Giving a liberal interpretation in application of the doctrine in, Forward Construction Co. v. Prabhat Mandal, ${ }^{13}$ the SC held that, "an adjudication is conclusive and final not only as to the actual matter determined but as to every other matter which the party might and ought to have litigated and have had decided as incidental to or essentially connected with subject matter of the litigation an every matter coming into the legitimate purview of an original action but in respect of the matter of claim and defence."

In Sulochana Amma v. Narayanan Nair, ${ }^{14} \mathrm{SC}$ has been observed that,

"Sec. 11 ( of $C P C$ ) embodies the rule of conclusiveness as evidence or bars as a plea an issue tried in an earlier suit founded on a plaint in which the matter is directly and substantially in issue and became final. In a later suit between the same parties or their privies in a court competent to try such subsequent suit in which the issue has been directly and substantially raised and decided in the judgment

\footnotetext{
${ }^{10}$ (2011) 3 SCC 408, para 80

11 A.I.R. 1960 S.C.94

${ }^{12}$ A.I.R. 1960 S.C. 941 at pg. 943

13 1986)1SCC 100; AIR 1986 SC 391

${ }^{14}$ AIR 1994 SC 152
}

and decree in the former suit would operate as res judicata. Sec. 11 does not create any right or interest in the property, but merely operates as a bar to try the same issue once over. In other words, it aims to prevent multiplicity of the proceedings and accords finality to an issue, which directly and substantially had arisen in the former suit between the same parties or their privies, been decided and became final, so that parties are not vexed twice over, vexatious litigation would be put to an end and the valuable time of the court is saved. It is based on public policy, as well as private justice. They would apply, therefore, to all judicial proceedings whether civil or otherwise. It equally applies to quasi-judicial proceedings of the tribunals other than the civil courts".

The object of finality of judgement/res judicata is to prevent multiplicity of judicial decision making on same subject matter/ having same cause of action. The doctrine helps in preventing addition to already pending and mounting number of cases.

Constructive res judicata

A sub-set of the doctrine of res judicata, emanating from Section 11 of the Code of Civil Procedure, the doctrine of constructive res judicata sets to naught any claims being raised in a subsequent proceeding where in an earlier proceeding such claim should/ought to have been raised and decided. A rule of prudence, thus, the doctrine seeks to bar determination and enforcement of claims which have not been raised at an appropriate juncture in judicial proceedings.

Workmen v. Board of Trustees, Cochin Port Trust, ${ }^{15}$ Supreme Court explained the Principle of Constructive Res Judicata in following words;

"If by any judgement or order any matter in issue has been directly and explicitly decided, the decision operates as res judicata and bars the trial of an identical issue in a subsequent proceeding between the same parties. The principle of res judicata also comes into play when by the judgement and order a decision of a particular issue is implicit in it, that is, it must be deemed to have been necessarily decided by implication; then also the principle of res judicata on that issue is directly applicable. When any matter which might and ought to have been made a ground of defence or attack in a former proceeding but was not so made, then such a matter in the eye of law, to avoid multiplicity of litigation and to bring about finality in it is deemed to have been constructively in issue and, therefore, is taken as decided.

\section{EXCEPTIONS TO APPLICATION OF FINALITY/RES JUDICATA}

In the case of Rural Litigation And Entitlement Kendra v. State of Uttar Pradesh, ${ }^{16}$ it was

15 (1978) 3 S.C.C. 119: A.I.R. 1978 S.C. 1283 
held that the writ petitions filed in the Supreme Court are not inter-party disputes and have been raised by way of public interest litigation and the controversy before the court is as to whether for social safety and for creating a hazardless environment for the people to live in, mining in the area must be permitted or stopped. Even if it is said that there was a final order, in a dispute of this type it would be difficult to entertain the plea of Res Judicata.

The decision of SC in this case is very important as it has left the public interest litigation petitions out from the purview of Res judicata. Since the interest of public at large is involved in PIL, application of res judicata may deny remedy in case of recurring cause of action like environmental pollution. Hence, exclusion of PIL from application of doctrine of res judicata is necessary.

Sunil Dutt v. Union of India ${ }^{17}$ dealing with writ petition filed, SC held that habeas corpus, filed under fresh grounds and changed circumstances will not be barred by a previous such petition.

per incuriam

'Incuria' means literally 'carelessness' which apparently is considered less uncomplimentary than ignorantia; but in practice 'per incuriam' applies to mean 'per ignorantiam'. It would almost seem that 'ignorantia juris neminem excusat' - except a Court of law, ignorance of what? Ignorance of a statute, or of a rule having statutory effect which would have affected the decision if the court had been aware of it. ${ }^{18}$

Judgments pronounced even by the Supreme Court in ignorance of statute law or a binding precedent are known as judgments per incuriam. Such judgments do not have THE authority of a precedent and need not be followed. ${ }^{19}$

The Hon'ble Supreme Court explained the concept of "per incuriam" as following:

"In Young v. Bristol Aeroplane Company Limited (1994) All ER 293 the House of Lords observed that 'Incuria' literally means 'carelessness'. In practice per incuriam appears to mean per ignoratium. English courts have developed this principle in relaxation of the rule of stare decisis. The 'quotable in law' is avoided and ignored if it is rendered, 'in ignoratium of a statute or other binding authority. The same has been accepted, approved and adopted by this court while interpreting Article 141

\footnotetext{
${ }^{16} 1985$ AIR 652, 1985 SCR (3) 169

${ }^{17}$ AIR 1982 SC 53, 1982 CriLJ 193, (1982) 3 SCC 405

${ }^{18}$ Allen C.K., Law in the Making, $7^{\text {th }}$ Ed. Oxford University Press, 1964, at pg. 246

${ }^{19}$ A Perspective on Precedents, http://jaassam.gov.in/pdf/article/Article-5.pdf
}

of the Constitution which embodies the doctrine of precedents as a matter of law." 20

\section{Tax Disputes}

Res judicata is not applicable to tax disputes as the liability under tax laws is dynamic and keeps on changing in every financial year.

\section{CONCLUSION}

In country like India where more than three crore cases are pending and the judiciary, with limited resources, is struggling to reduce the pendency of cases, finality of judgement/res judicata plays a vital role. The principle of finality of litigation is based on a sound firm principle of public policy. The doctrine of finality/res judicata is evolved with an object of to preventing unnecessary litigation under the colour and pretence of law. Doctrine of finality/res judicata ensures end to litigation in public interest.

\footnotetext{
${ }^{20}$ Siddharam Satlingappa Mhetre v. State of Maharashtra, (2011) 1 SCC 694 At Para 139
} 